\title{
Selected trace elements and metals in groundwater within Permian sediments near Olkusz (Zn-Pb ore mining region, S Poland)
}

\author{
Adam Postawa $^{1}$ D Jacek Motyka ${ }^{1}$ \\ Received: 28 February 2018 / Accepted: 14 August 2018 / Published online: 10 September 2018 \\ (C) The Author(s) 2018
}

\begin{abstract}
The extensive mining of $\mathrm{Zn}-\mathrm{Pb}$ ores in the Olkusz region resulted in significant changes of both water table level and chemical composition of water in all aquifers in the area. This was caused by intensive dewatering of mining excavations and development of a thick aeration zone reaching $150 \mathrm{~m}$ in a central part of the area. That created favorable conditions for oxidation of metal sulfides occurring in the ore-bearing dolomites (Middle Triassic) and started the process of forming readily soluble hydroxysulphates which then migrated to lower aquifers, including the Permian. As a result of those processes, various metals and other elements toxic to the water environment appeared in leaks observed in mine galleries. Changes in concentrations of selected elements (Fe, Mn, $\mathrm{Zn}, \mathrm{Pb}, \mathrm{Cu}, \mathrm{Ba}, \mathrm{Ni}, \mathrm{Co}, \mathrm{As}, \mathrm{Cr}, \mathrm{Hg}, \mathrm{Tl}, \mathrm{Ag}, \mathrm{Cd}, \mathrm{B}$ ) in mine waters over the period of the last nearly 50 years were described. Water samples were collected from exploratory boreholes, piezometers, and wells located in investigated area inflows and seepages occurring in shafts and drifts excavated in Permian conglomerates. Mean concentrations of metals $(\mathrm{Pb}, \mathrm{Cd}, \mathrm{Cr}, \mathrm{Hg}, \mathrm{Tl})$ and other toxic elements were surprisingly low; $\mathrm{Pb}, 3.94 \mu \mathrm{g} / \mathrm{L} ; \mathrm{Cd}, 0.2 \mu \mathrm{g} / \mathrm{L} ; \mathrm{Cr}$, up to $2.26 \mu \mathrm{g} / \mathrm{L} ; \mathrm{Hg}$, $0.25 \mu \mathrm{g} / \mathrm{L} ; \mathrm{Tl}, 3.59 \mu \mathrm{g} / \mathrm{L}$; and As, $6.31 \mu \mathrm{g} / \mathrm{L}$. However, the observed concentrations varied significantly over time, reaching respectively up to $190 \mu \mathrm{g} \mathrm{Pb} / \mathrm{L}, 60 \mu \mathrm{g} \mathrm{Cd} / \mathrm{L}, 15.6 \mu \mathrm{g} \mathrm{Cr} / \mathrm{L}, 2.67 \mu \mathrm{g} \mathrm{Hg} / \mathrm{L}, 81.3 \mu \mathrm{g} \mathrm{Tl} / \mathrm{L}$, and $155 \mu \mathrm{g} \mathrm{As} / \mathrm{L}$.
\end{abstract}

Keywords Neutral mining drainage $\cdot \mathrm{Zn}-\mathrm{Pb}$ ore mining $\cdot$ Heavy metals $\cdot$ Toxic elements $\cdot$ Olkusz region

\section{Introduction}

Underground mining of ore deposits usually leads to significant changes in surrounding environments. It affects land surface and both surface and groundwater. From a hydrogeological point of view, the most important is changes in water table levels and transformations of the chemical composition of groundwater. Depending on the type of rock hosting the ore and the type of ore minerals, the influence on water chemistry could vary significantly but usually leads to deterioration of water quality. The most common phenomenon associated with sulfide-type

Responsible editor: Severine Le Faucheur

Adam Postawa

postawa@agh.edu.pl

Jacek Motyka

motyka@agh.edu.pl

1 AGH University of Science and Technology, Al. Mickiewicza 30, 30-059 Krakow, Poland ores is the production of acidic solutions, which result from oxidation of various metals' sulfides (e.g., pyrite, marcasite). The problem of acid mine drainage or acid rock drainage is widely described in literature (e.g., Banks et al. 1997; Gray 1997; Sainz et al. 2003, 2004 Johnson and Hallberg 2005; Grande et al. 2010, 2013, 2018; Bauerek et al. 2013), but some aspects of neutral or circumneutral drainage are still not fully recognized. This applies to ore deposits occurring in carbonate rocks and the presence of toxic metals and other microelements in mine waters. Problems induced by ore mining do not stop with mine closure but continuously affect the environment for many decades (Younger 1997; Cidu et al. 2001; Leblanc et al. 2000; Aykol et al. 2003; Cidu et al. 2005; Cidu et al. 2009; Frau et al. 2009; Sracek et al. 2011, 2012; Majzlan et al. 2018).

Sulfide ores of zinc and lead occur in numerous locations in the world. One of them is the Olkusz $\mathrm{Zn}-\mathrm{Pb}$ ore mining region (Mississippi-Valley-type $\mathrm{Zn}$-Pb ore region). Geologically, it is a part of the Cracow-Silesian monocline, a regional tectonic structure with the SE-NW direction formed as a result of the Alpine orogeny and located in southwestern Poland. It 
consists of Mesozoic, Triassic, Jurassic, and Cretaceous formations overlying discordantly on the fault bend fold Paleozoic structures formed during the Variscan orogeny.

Lead and zinc mining in the Olkusz region reaches back to neolith, which was confirmed by documents from the twelfth century. Initially, galena rich in silver was extracted from Triassic deposits located above the groundwater level. In the seventeenth century, a few adits were excavated to drain water from ore-bearing rocks and allow the exploitation to reach deeper. It resulted in depletion of the water table by $30 \mathrm{~m}$ in surrounding areas. This moment is considered the beginning of mining drainage in the Olkusz area. The most intensive mining drainage of the Triassic aquifer dates back to the second half of the twentieth century. It related to the development of the Bolesław mine and then establishing two new mines called: Olkusz and Pomorzany. Construction of the Pomorzany mine, which began in 1969 , is especially important. The main accessing excavations of this mine were carried out in the Permian sediments (molasses) that underlie Triassic sediments. Starting from the early 1990s, another part of the $\mathrm{Zn}-\mathrm{Pb}$ deposit was accessed by the Olkusz-sublevel mine and by galleries carried out in the Permian molasse.

Intensive mining drainage caused the development of a large regional cone of depression with an estimated surface area of about $350 \mathrm{~km}^{2}$ (Adamczyk 1990). In the central part of this area, the water table has dropped about $150 \mathrm{~m}$ (in the Triassic aquifer). The decrease of the water table was observed in all aquifers, including Quaternary, Jurassic, and Permian. That created a thick aeration zone and facilitated favorable conditions for oxidation of sulfate minerals occurring in abundance in Triassic carbonates. As a result of this process, large quantities of acidic solutions were produced, which were then buffered in contact with carbonate rocks (limestones and dolomites). A $\mathrm{pH}$ value of mine waters from leaks observed in the galleries carried out in Permian sediments has not changed significantly. It ranges from 6.4 to 8.4 , at the initial stage of Pomorzany mine development in the early 1970 s to $6.1-9.14$ in 2015. However, important changes in the chemical type of water were observed. Within the Permian aquifer, the chemical type of the water has evolved significantly (Motyka and Czop 2006; Motyka and Postawa 2013).

Fluctuations of $\mathrm{pH}$ value and moreover changes in oxidation-reduction conditions facilitated mobility of Fe, $\mathrm{Mn}$, and other red-ox sensitive elements. Some of them are well known as elements toxic to humans (e.g., $\mathrm{Pb}, \mathrm{Hg}, \mathrm{Ni}$, As, $\mathrm{Cd}, \mathrm{Cr}, \mathrm{Sb}, \mathrm{Tl}$, or U) (Borgmann et al. 1998; Kazantzis 2000; Bagchi et al. 2002; WHO 2011; Riyaz et al. 2013; Belzile and Chen 2017; Lukaszewski et al. 2018; Pavoni et al. 2018). Some of the investigated elements are not considered severely toxic to humans, but they are still toxic to organisms living in a water environment (e.g., $\mathrm{Zn}, \mathrm{Cu}, \mathrm{B}, \mathrm{Ag}, \mathrm{Co}$ ) (Hogstrand and Wood 1998; Marr et al. 1998; De Schamphelaere et al. 2007; Ebrahimpour et al. 2010; Brix et al. 2011).
The primary goal of this study was a characterization of the chemical composition of groundwater occurring within Permian sediments, especially in regard to metals and other trace elements. It was also an attempt to assess the influence of long-term mining activities carried out in the investigated area on the contents of these elements. It is an attempt to summarize and utilize the results of nearly 50 years of collecting unique hydro-chemical data.

\section{Materials and methods}

\section{Geological settings}

Figure 1 presents a synthetic geological profile from the Olkusz region. It also presents hydraulic conductivities (estimated ranges of orders of magnitudes) of main rock types occurring in the area.

During Permian, in the Olkusz region, Variscan tectonic movements formed a narrow but relatively deep midmontane trench of the NW-SE direction between the elevated tectonic blocks of Upper Silesia and Lesser Poland (Buła 2000). This trench was covered with typical molassic formations, which consist mainly of conglomerates of fragments from older Paleozoic rocks, mostly limestones and Devonian and Carboniferous dolomites, as well as quartzites, porphyries, and melaphyres. The maximum thickness of the Permian sediments reaches approximately $300 \mathrm{~m}$ (Fig. 1).

Triassic rocks are located discordantly on different Paleozoic sediments. They are represented by the sediments of the Middle and Upper Triassic: Rhaetian, Mushelkalk, and Keuper. The Mushelkalk is composed of carbonate rocks, mainly limestones and dolomites, including also metasomatic ore-bearing dolomites, with $\mathrm{Zn}-\mathrm{Pb}$ ore deposits. The primary ore minerals include sulfides of zinc (sphalerite) and lead (galena), accompanied by copious amounts of iron sulfides (i.e., pyrite and marcasite) (Sass-Gustkiewicz 1997; Mayer and Sass-Gustkiewicz 1998). In zones where the deposits are oxidized, calamines (gossans) occur. The thickness of shell limestone deposits reaches approximately $110 \mathrm{~m}$ (Fig. 1). The Upper Triassic deposits (Keuper) are formed in the terrestrial facies with interlayers of shallow sea facies deposits. Spotted clays, claystones, and shales prevail there, among which there are thin inserts of carbonate rocks and sandstones. The thickness of Upper Triassic rocks reaches approximately $200 \mathrm{~m}$ (Fig. 1).

The Jurassic sediments occur in the northern and eastern parts of the Olkusz region. They are represented by the Middle and Upper Jurassic rocks. The Middle Jurassic rocks include mostly marls and subordinately also clay-conglomerate rocks. The thickness of the Dogger rocks is small and usually falls within the range of 10-30 m. The Upper Jurassic (Malm) includes mostly different lithological variations of limestones 
Fig. 1 Synthetic geological profile of the Olkusz region

\begin{tabular}{|r|r|r|r|}
\hline & \\
\hline
\end{tabular}

with the marl layer in the bottom part. The thickness of the Malm deposits reaches approximately $200 \mathrm{~m}$ (Fig. 1).

Mesozoic and Paleozoic rocks are covered by Quaternary sediments. They are dominated by fluvioglacial sands with gravel, rubble, dust, silt, and clay inserts. On hilltops, built of older rocks, these are weathered clays (regolite) with a thickness of 1-2 m. The thickness of fluvioglacial deposits is usually within the range of 20-30 $\mathrm{m}$ (Fig. 1).

\section{Hydrogeological conditions}

In the Olkusz region, there are five aquifers: Quaternary, Jurassic, Triassic, Carboniferous, and Devonian (Wilk and Motyka 1977).

A Quaternary aquifer is formed by sands with gravel inserts. The geometric mean value of the hydraulic conductivity for these sediments, determined based on the results of pumping tests, is equal to $2.5 \cdot 10^{-4} \mathrm{~m} / \mathrm{s}$ (Motyka and Wilk 1976). This aquifer is recharged by infiltrating atmospheric precipitation and by the inflow of water from other aquifers in areas of direct and indirect hydraulic contact. It is drained by surface watercourses and by the outflow of water to lower situated aquifers in the area influenced by mining drainage of the Olkusz $\mathrm{Zn}-\mathrm{Pb}$ ore mines.
The Jurassic aquifer is built by platy, rocky, and chalky limestones of the Upper Jurassic. It is a fissure-karst type of aquifer. The geometric mean value of the hydraulic conductivity, determined during pumping tests, amounts to $1.6 \cdot 10^{-5} \mathrm{~m} / \mathrm{s}$ (Motyka and Wilk 1976). It is recharged by infiltrating atmospheric precipitation and drained by surface watercourses, intake wells, and outflow of water to other aquifers in areas of direct and indirect hydraulic contact (Wilk and Motyka 1977).

The Triassic aquifer is formed by dolomites and limestones of upper Bundsandstein and Mushelkalk. It is a pore-fissure-karst type aquifer (Motyka 1988; Motyka 1998). The geometric mean value of hydraulic conductivity of Triassic carbonates is equal to $6.5 \cdot 10^{-5} \mathrm{~m} / \mathrm{s}$ (Motyka and Wilk 1976). The dichotomy of permeability of these rocks is apparent, as the modal value of hydraulic conductivity for the shell limestone is approximately $9.0 \cdot 10^{-5} \mathrm{~m} /$ $\mathrm{s}$, while for the Bundsandstein sediments are approximately $7.0 \cdot 10^{-6} \mathrm{~m} / \mathrm{s}$ (Motyka and Wilk 1976). The discussed aquifer is supplied by infiltrating atmospheric precipitation in areas of its outcrop and by the inflow of water from other aquifers in areas of direct and indirect hydraulic contact. Infiltration of water from surface watercourses in areas covered by the drainage of the Olkusz $\mathrm{Zn}-\mathrm{Pb}$ ore mines is an essential element of groundwater recharge. 
The Triassic aquifer is drained mainly by excavations of these mines, where currently about $5 \mathrm{~m}^{3} / \mathrm{s}$ of water flows in.

Carbonate Carboniferous and Devonian rocks form a common Paleozoic aquifer complex. It is a fissure-karst type aquifer. It is poorly investigated in terms of hydrogeological characteristics. The values of hydraulic conductivity, determined based on the results of pumping tests in two boreholes, were $7.6 \cdot 10^{-6} \mathrm{~m} / \mathrm{s}$ and $7.0 \cdot 10^{-5} \mathrm{~m} / \mathrm{s}$ respectively. Recharge and drainage of the Paleozoic aquifer occur in the areas of hydraulic contacts with other aquifers (Adamczyk et al. 1978).

Permian conglomerates are sometimes considered semipermeable sediments from a water supply standpoint (in terms of hydrogeological properties). The study on permeability, conducted in 14 boreholes, allowed determination of the hydraulic conductivity of these rocks. Values of these parameters fit within a wide range (i.e., from 1.0. $10^{-8}$ to $\left.1.6 \cdot 10^{-5} \mathrm{~m} / \mathrm{s}\right)$. Conglomerates have a higher permeability in the zones of fractures, associated with faults (Motyka and Postawa 2013).

The schematic hydrogeological cross-sections (Fig. 2) present the situation at the initial stage (prior to extensive mining) compared to the situation from around 1985. Significant changes in water table levels were caused by intensive dewatering of mining galleries.

\section{Mining context}

In the second half of the twentieth century, there were three active mines of $\mathrm{Zn}-\mathrm{Pb}$ ores in the Olkusz region (i.e., Bolesław, Olkusz, and Pomorzany). Mining excavations in the Permian conglomerates were performed in the Pomorzany mine at the level of about $+175 \mathrm{~m}$ a.s.l., due to the approved project of releasing $\mathrm{Zn}-\mathrm{Pb}$ ore deposits, lying in the down-throw side of the Pomeranian fault, a regional dislocation in this area. According to the abovementioned project, the Pomorzany deposits started to be released in 1969 by excavations drilled from the Olkusz mine, whose main excavations were located at $+235 \mathrm{~m}$ a.s.l. in carbonate Triassic rocks. Therefore, completion of the project intended to release this deposit, which required a suitable system of excavations in the Permian conglomerates that would allow crossing the Pomorzany fault. The first excavations crossed the Pomorzany fault in September 1973.

Due to the depletion of $\mathrm{Zn}-\mathrm{Pb}$ ore resources, the Bolesław mine was closed in 1996, and its excavations were spontaneously flooded. Submersible pumps were installed in the main shaft to intake industrial water. In 1999, the closure of the Olkusz mine began, but its dewatering was maintained due to the exploitation safety reasons of the Olkusz-sublevel Zn$\mathrm{Pb}$ ore deposits lying about $60 \mathrm{~m}$ below the drain galleries of the closed down Olkusz mine.
Fig. 2 Schematic hydrogeological cross-section across the Olkusz region: a Natural conditions. b A period of intensive mining activities (around 1985)

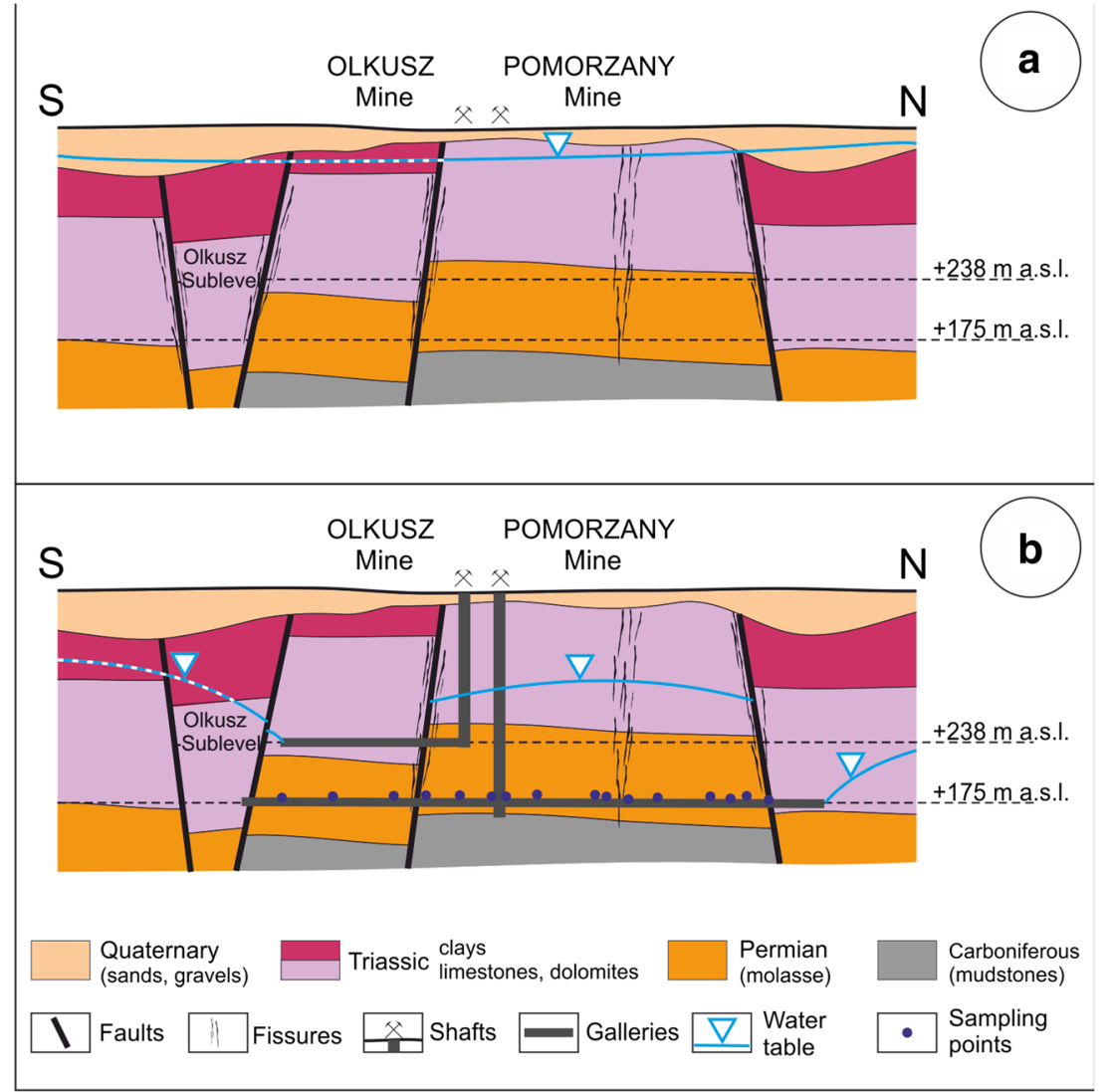


Zinc and lead ores are currently exploited in the Olkusz region only in the Pomorzany mine and within the mentioned Olkusz-sublevel deposit.

\section{Sampling}

The samples of water from leaks from the Permian conglomerates released by the mining excavations of the "Pomorzany" mine have been collected since 1971 (i.e., since they appeared). Until 1976, the water samples were collected with the progress of mining works and implementing of the part of the project on releasing the Pomorzany deposits, which concerned mining excavations in the Permian conglomerates. After some time, some of the leaks disappeared, and only a few of them were permanent enough to allow collection of water samples for several years. Until now, from the total initial population of about 80 leaks, only 20 leaks are accessible, from which water samples were collected with variable frequency, usually every 2-3 years. During the period of 1980-1995, the samples of water were collected very rarely and only from some of the active leaks from the Permian conglomerates. For this reason, there is no continuity of sampling during this period. The last samples were collected in 2016. Locations of sampled leaks are presented on a map showing main galleries of Pomorzany and Olkusz mines (Fig. 3).

Samples were also collected from exploratory boreholes drilled during deposit documentation and exploration stages, piezometers, and wells located in the investigated area. In total, over 400 samples were collected during the investigation period (1967-2016). However, one should keep in mind that the numbers of samples and the numbers of determinations of particular ions/elements are not the same. Unfortunately, in many samples, only selected parameters were determined; thus, the number of useful results of microelements' determinations is smaller and varies from 193 determinations for cadmium up to 255 for zinc.

All samples were collected as non-filtered samples and delivered to a laboratory within $24 \mathrm{~h}$. Since 1990, directly upon delivery to the laboratory, samples were filtered using $0.45 \mu \mathrm{m}$ filters, and part of each sample intended for metals determination was acidified with nitric acid to a $\mathrm{pH}<2$.

\section{Analytical methods}

Chemical analyses of all samples were performed by a hydrogeochemical laboratory of Department of Hydrogeology and Engineering Geology, AGH University, Krakow. In 2009, the laboratory was accredited by the Polish Centre for Accreditation (accreditation number AB 1050). The laboratory has fully implemented an internal quality assurance and quality control system $(\mathrm{QA} / \mathrm{QC})$, which fulfills the requirements of the ISO/IEC 17025 standard. The QA/QC system is based on analyses of control samples (blanks, duplicates, and spiked samples) and certificated standard materials (ION96.3, ION-96.64, and TMDA-4.3 by Environment and Climate Change Canada and 1643a and 1643 e by the U.S. National Institute of Standards and Technology). The laboratory participates in proficiency-testing programs and interlaboratory comparisons (both national and international) achieving satisfying results.

Chloride concentrations were determined using the Mohr method (i.e., titration with silver nitrate, in accordance with ISO 9297 standard). Concentrations of hydrocarbonates were calculated on the basis of alkalinity determinations, which were performed by titration with hydrochloric acid. Sulfate concentrations, until 1990, were determined using the gravimetric method with drying of residue.

The total sulfur content was determined, and then sulfate concentration was calculated. In samples collected before 1990, calcium was determined by titration with ethylenediaminetetraacetic acid (EDTA). Magnesium concentrations were calculated on the basis of total hardness and calcium. Sodium and potassium concentrations were determined by flame emission photometry. Since 1990, all these metals have been determined using the inductively coupled plasma atomic emission spectrometry (ICP-AES) method.

Since 2001, concentrations of all microelements were determined using the inductively coupled plasma mass spectrometry (ICP-MS) method (ELAN 6100 spectrometer, PerkinElmer). This allowed for significant improvement in the quality of metals' determinations in terms of practical detection limits.

\section{Results and discussion}

Samples collected from the leaks during the period of drilling mining excavations in the Permian conglomerates presented very diversified chemical compositions. Total dissolved solids (TDS) of these waters ranged from 0.33 to $21.6 \mathrm{~g} / \mathrm{L}$, whereas its dependence on the depth of the leak with respect to the Permian conglomerate roof was evident (Motyka and Postawa 2013). In waters with the lowest TDS, $\mathrm{Ca}, \mathrm{Mg}$, and $\mathrm{HCO}_{3}$ ions dominated; while with increasing TDS, the share of $\mathrm{Na}, \mathrm{SO}_{4}$, and $\mathrm{Cl}$ ions increased. Therefore, the hydro-chemical type of water has changed from Ca-Mg- $-\mathrm{HCO}_{3}$ for waters with TDS of $0.5 \mathrm{~g} / \mathrm{L}$ through multi-ion waters with different combinations of the main ions to the $\mathrm{Na}-\mathrm{Cl}$ type for waters with TDS value of $10-20 \mathrm{~g} / \mathrm{L}$. It was accompanied by an increase in average concentrations of all major ions except for potassium (Fig. 4).

With the progress of mining works, the TDS of leaks observed in earlier-excavated galleries decreased very quickly due to the inflow of fresh water from the upper part of the Permian conglomerates and the overlying Triassic deposits. The share of calcium and magnesium ions in the chemical composition of water from those leaks increased significantly. 
Fig. 3 Location of sampling points

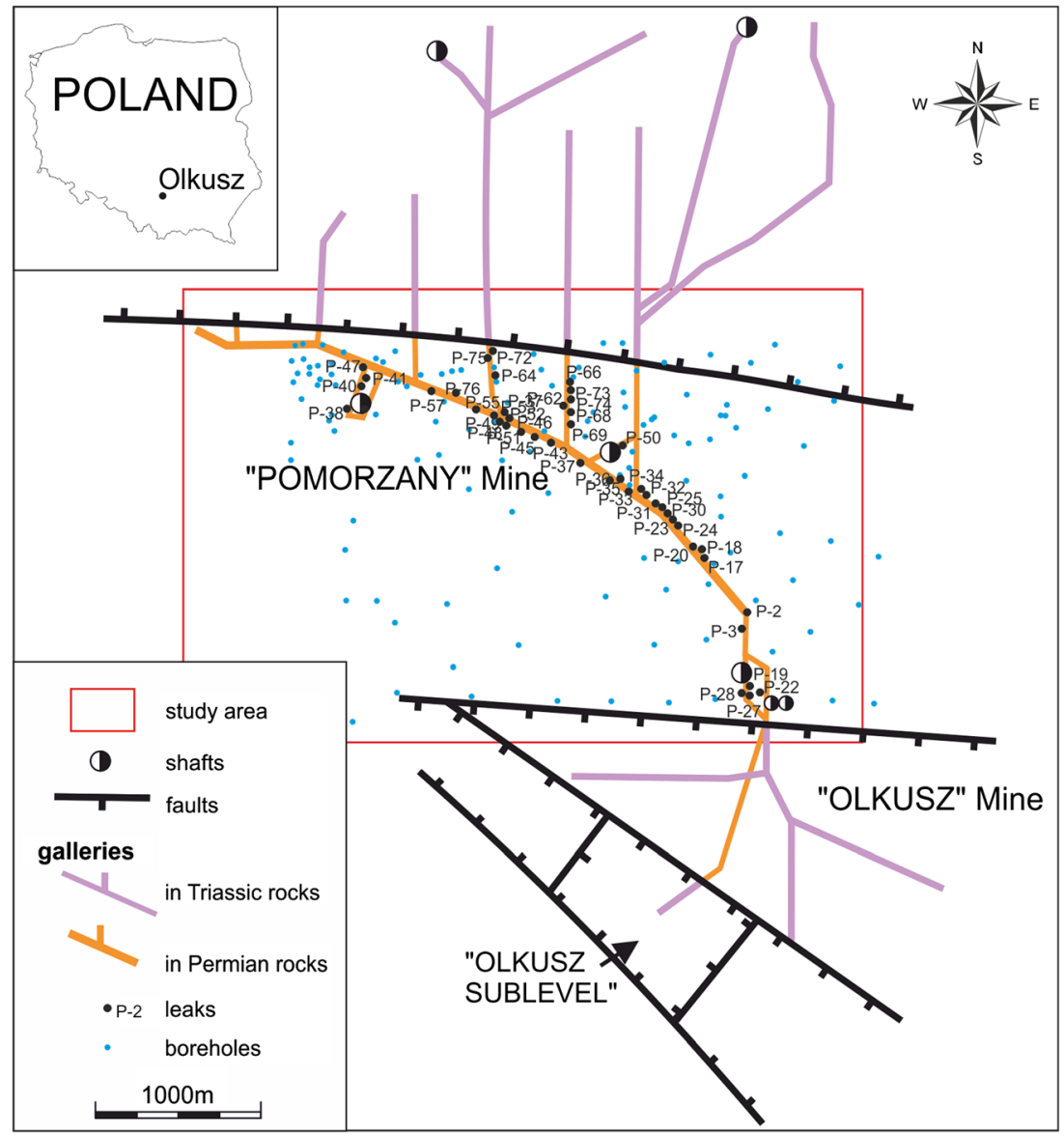

After 1985, when a new quasi-fixed hydrodynamic balance in conditions of mining drainage of the Permian conglomerates was established, most leaks ceased to exist. Only those from the western part of the mine excavations remained active, which were recharged mainly with water from the overlying ore-bearing Triassic deposits. Readily soluble hydroxysulphates of calcium (gypsum), magnesium (epsomite, hexahydrite), and iron (melanterite) were formed because of weathering sulfide minerals (mostly marcasite) occurring in these rocks. The inflow of water with high TDS from the Triassic aquifer changed the original character of leakage waters from the Permian deposits. It could be
Fig. 4 Concentrations of major ions in groundwater in Permian aquifer

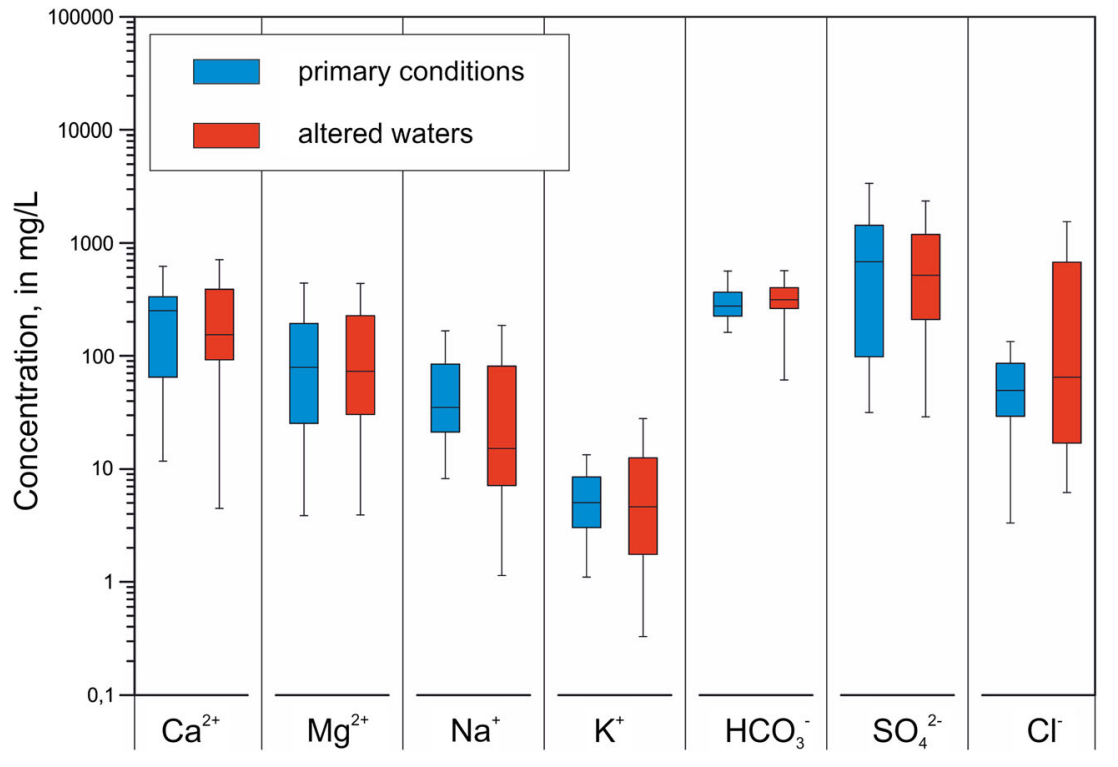


observed that TDS values significantly increased to a few or several grams per liter, while the hydro-chemical type had changed from $\mathrm{Ca}-\mathrm{Mg}-\mathrm{HCO}_{3}$ to $\mathrm{Ca}-\mathrm{Mg}-\mathrm{SO}_{4}$ and $\mathrm{Mg}-\mathrm{Ca}-\mathrm{SO}_{4}$ to $\mathrm{Mg}_{-} \mathrm{SO}_{4}$. It is a typical phenomenon, commonly occurring in such conditions (Hermann and Neumann-Mahlkau 1985; Lee et al. 2001; Cidu et al. 2007; Hidalgo et al. 2010).

By the mid-1980s, the concentration of iron, manganese, zinc, and lead only had been analyzed in a few samples. The iron concentration ranged from 0.04 to $2.6 \mathrm{mg} / \mathrm{L}$ (mean of $0.36 \mathrm{mg} / \mathrm{L}$ ), manganese from 0.02 to $0.07 \mathrm{mg} / \mathrm{L}$ (mean of $0.025 \mathrm{mg} / \mathrm{L}$ ), zinc from 0.13 to $5.7 \mathrm{mg} / \mathrm{L}$ (mean of $0.31 \mathrm{mg}$ / $\mathrm{L}$ ), and lead from 0.06 to $0.19 \mathrm{mg} / \mathrm{L}$ (mean of $0.08 \mathrm{mg} / \mathrm{L}$ ). It should be emphasized here that different analytical methods used at that time provided inconsistent results and allowed detection of an element only when its concentration in the aqueous solution was significantly higher compared to that with the currently used, more advanced, analytical methods.

Starting from 1990, the use of new analytical methods, ICP-AES and ICP-MS (since 2001), allowed for a considerable increase in the number of analyzed microelements and to reach the detection level of parts of micrograms per liter. Samples collected from leaks in the period of 20012016 (241 samples) retained almost unchanged chemical composition, similar to those recorded in the 1980s. That occurred, probably, after the stabilization of the new hydrodynamic balance caused by mine drainage. The concentration of iron in these samples ranged from 0.007 to $40.1 \mathrm{mg} / \mathrm{L}$, manganese from 0.0009 to $3.96 \mathrm{mg} / \mathrm{L}$, zinc from 0.013 to $69.8 \mathrm{mg} / \mathrm{L}$, and lead from 0.00008 to $0.135 \mathrm{mg} / \mathrm{L}$ (see Table 1).

Lack of reliable data covering the whole investigated period does not allow clear determination of how the concentrations of microelements have changed. Only the past 20 years of water leaks from the Permian deposits could be included in this study. However, in 2001 and 2007, samples collected from three leaks showed chemical composition practically identical to the composition observed before 1985. It can be assumed that the results of analyses of water from the abovementioned three leaks can be used as a reference level. The concentrations of Fe, Mn, $\mathrm{Zn}, \mathrm{Pb}, \mathrm{Ni}, \mathrm{Co}, \mathrm{Tl}, \mathrm{Cd}$, and $\mathrm{Al}$ in waters of the entire examined population of leaks are significantly higher than in water not affected by chemical transformation. Similar concentrations in both separated collections of water were found for $\mathrm{Ba}, \mathrm{As}, \mathrm{Cr}$, and $\mathrm{Sb}$.

Summary statistics for all sampled points are presented in Table 1. The results are divided into two groups: a group representing samples collected prior to 1985 representing "primary conditions" and a group representing samples collected after 1995 (i.e., with the chemical composition significantly altered by mining activities).

Average concentrations of most studied microelements do not exceed parametric values established for drinking water (98/83/EC 1998) and guideline values recommended by the WHO (2011), as presented in Fig. 5. The only exceptions are bromates, iron, manganese, and nickel. The mean concentration of iron in the whole studied period (1967-2016) was

Table 1 Concentrations of selected elements in water within Permian sediments near Olkusz. Summary statistics

\begin{tabular}{|c|c|c|c|c|c|c|c|c|c|c|c|}
\hline & \multicolumn{5}{|c|}{$1967-1985$} & \multicolumn{5}{|c|}{ 1985-2016 } & \multirow[t]{2}{*}{ 98/83/EC parametric value } \\
\hline & $\mathrm{N}$ & AVG & Median & $\operatorname{Max}$ & SD & $\mathrm{N}$ & AVG & Median & Max & SD & \\
\hline Element & - & $\mathrm{mg} / \mathrm{L}$ & & & & - & \multicolumn{4}{|c|}{$\mathrm{mg} / \mathrm{L}$} & $\mathrm{mg} / \mathrm{L}$ \\
\hline $\mathrm{Ag}$ & 0 & - & - & - & - & 241 & 0.127 & 0.0002 & 2.05 & 0.376 & - \\
\hline $\mathrm{Al}$ & 2 & 0.022 & 0.022 & 0.04 & 0.025 & 214 & 0.0098 & 0.0004 & 0.202 & 0.0282 & 0.2 \\
\hline As & 1 & 0.01 & 0.01 & 0.01 & - & 204 & 0.008 & 0.0036 & 0.155 & 0.015 & 0.01 \\
\hline B & 3 & 1.75 & 1.78 & 1.91 & 0.45 & 204 & 0.069 & 0.034 & 0.388 & 0.085 & 1.0 \\
\hline $\mathrm{Ba}$ & 0 & - & - & - & - & 241 & 0.378 & 0.027 & 12.600 & 1.22 & - \\
\hline $\mathrm{Br}$ & 23 & 9.47 & 1.61 & 76.7 & 21.6 & 204 & 0.063 & 0.027 & 0.581 & 0.088 & 0.01 \\
\hline $\mathrm{Cd}$ & 3 & 0.0273 & 0.017 & 0.06 & 0.0289 & 190 & 0.0092 & 0.0002 & 0.6 & 0.0316 & 0.05 \\
\hline $\mathrm{Cr}$ & 0 & - & - & - & - & 204 & 0.001 & 0.0022 & 0.0156 & 0.002 & 0.05 \\
\hline $\mathrm{Fe}$ & 8 & 3.04 & 0.355 & 2.6 & 1.870 & 237 & 2.44 & 0.459 & 40.69 & 5.23 & 0.2 \\
\hline $\mathrm{Hg}$ & 0 & - & - & - & - & 204 & 0.00042 & 0.00025 & 0.00267 & 0.00083 & 0.001 \\
\hline $\mathrm{Mn}$ & 3 & 0.037 & 0.02 & 0.07 & 0.029 & 241 & 0.398 & 0.153 & 3.963 & 0.569 & 0.05 \\
\hline $\mathrm{Ni}$ & 0 & - & - & - & - & 205 & 0.0425 & 0.027 & 0.372 & 0.095 & 0.02 \\
\hline $\mathrm{Pb}$ & 9 & 0.106 & 0.08 & 0.19 & 0.052 & 204 & 0.0055 & 0.0039 & 0.19 & 0.0128 & 0.01 \\
\hline $\mathrm{Se}$ & 1 & 1.05 & 1.05 & 1.05 & - & 204 & 0.008 & 0.003 & 0.107 & 0.015 & 0.01 \\
\hline $\mathrm{Tl}$ & 0 & - & - & - & - & 204 & 0.006 & 0.0036 & 0.081 & 0.01 & - \\
\hline $\mathrm{Zn}$ & 11 & 5.002 & 0.31 & 51.7 & 15.4 & 244 & 4.25 & 1.24 & 69.8 & 7.52 & - \\
\hline
\end{tabular}

$N$, number of determinations; $A V G$, arithmetic mean; $S D$, standard deviation. 
Fig. 5 Concentrations of selected elements in water samples from mine leaks in the Olkusz region (box-whiskers plot without outliers)

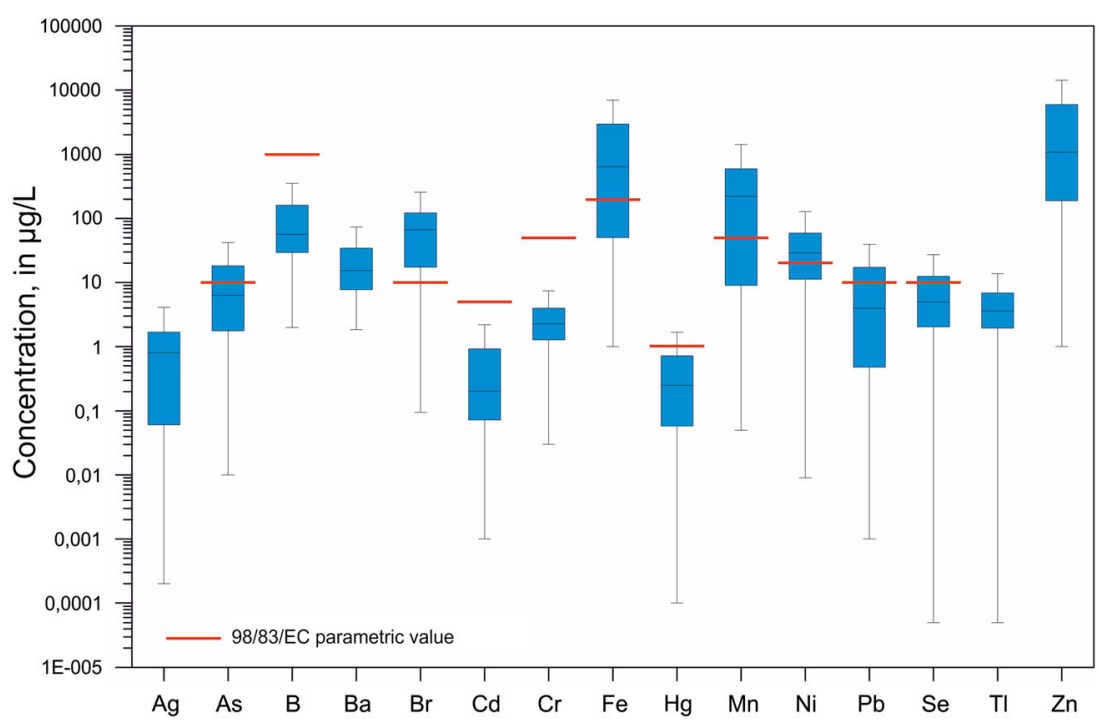

$2.7 \mathrm{mg} / \mathrm{L}$, manganese $0.39 \mathrm{mg} / \mathrm{L}$, and nickel $42.5 \mu \mathrm{g} / \mathrm{L}$ (however, concentrations of nickel were analyzed since 2001). The concentrations of lead, arsenic, and selenium only occasionally exceeded the parametric values (98/83/EC 1998). It is not possible to identify clear links between the degree of groundwater transformation caused by mining activity and concentrations of these elements. Elevated concentrations of iron manganese, nickel, arsenic, and other metals in both groundwater and surface water in the areas of $\mathrm{Zn}-\mathrm{Pb}$ ore mining are reported in numerous studies (e.g., Cidu et al. 2001; Aykol et al. 2003; Sainz et al. 2004; Lee et al. 2005; Hidalgo et al. 2010; Sracek et al. 2012; Bauerek et al. 2013).

The highest concentration of all metals reached was zinc. Concentrations of this metal varied from single micrograms per liter to $69.8 \mathrm{mg} / \mathrm{L}$. A high concentration of $\mathrm{Zn}$ in water is expected in existing conditions, as it was described by Cidu and others (Cidu et al. 2005).

However, the most concerning from a toxicological point of view are relatively high concentrations of thallium, which is well-known as a highly toxic element (Borgmann et al. 1998; Kazantzis 2000; Xiao et al. 2012; Belzile and Chen 2017). Concentrations of thallium in water from the Permian aquifer reached $81 \mu \mathrm{g} / \mathrm{L}$. The parametric value in drinking water is not regulated in most countries, including EU. In the U.S.A., the Environmental Protection Agency has set a maximum contaminant level (MCL) in drinking water at $2.0 \mu \mathrm{g} / \mathrm{L}$ (with a maximum contaminant level goal, MCLG, of $0.5 \mu \mathrm{g} / \mathrm{L}$ ).

The evolution of chemical composition of water from leaks from the Permian conglomerates in the initial phase of the mining drainage (transient conditions) consisted of reducing their TDS value because of freshwater inflow from the overlying Triassic aquifer (Motyka and Postawa 2013). The new hydrodynamic balance in the surroundings of mining excavations was stabilized approximately around 1985. This is confirmed by the results of monitoring of changes in the concentration of $\mathrm{Cl}$ ions in the selected leaks from the Permian deposits.

Weathering of sulfide minerals, which occurred in the orebearing dolomites (Middle Triassic), affected by the mining drainage, initiated the process of producing readily soluble hydroxysulphates (mainly of calcium, magnesium, and iron). Water from the Triassic aquifer, containing sulfates, calcium, and magnesium in high concentration, infiltrated the underlying Permian conglomerates (Motyka and Czop 2006; Motyka and Postawa 2013). Infiltrating water contained elements present in sulfides of iron, zinc, and lead as well. The concentration of the latter depended on their mobility and solubility of secondary minerals of these microelements in the geochemical environment reach in carbonate rocks (Hermann and Neumann-Mahlkau 1985; Hidalgo et al. 2010; Pavoni et al. 2018). Therefore, the highest concentrations were found for zinc (up to $69.8 \mathrm{mg} / \mathrm{L}$ ) and iron (up to $40.7 \mathrm{mg} / \mathrm{L}$ ). The process that inhibits the passage of iron to the aqueous solution is the precipitation of hydro-oxides of this element on the sidewalls of mining excavations. There were high concentrations of manganese, reaching up to $3.9 \mathrm{mg} / \mathrm{L}$, found in leaks with a high proportion of water transformed by the above-discussed geochemical processes.

Because of the oxidation process of iron, zinc, and lead sulfides, there are abnormally high concentrations of some microelements in the transformed aqueous solutions. There are elevated contents of nickel, cobalt, and arsenic in the iron sulfides (marcasite, pyrite). The concentrations of these microelements in waters with transformed chemical composition reached $0.372 \mathrm{mg} \mathrm{Ni} / \mathrm{L}, 0.015 \mathrm{mg} \mathrm{Co} / \mathrm{L}$, and $0.155 \mathrm{mg} \mathrm{As} / \mathrm{L}$. Zinc sulfides (sphalerite, wurtzite) are reached in cadmium (Mayer and Sass-Gustkiewicz 1998), thus, are the most probable source of cadmium in groundwater (Cidu et al. 2007). The concentration of $\mathrm{Cd}$ in transformed waters reaches $0.26 \mathrm{mg} / \mathrm{L}$. Since the Middle Ages, galena was also used for 
the recovery of silver during metallurgical processing of lead ore. Galena, which contains increased levels of silver and thallium, could be a source of these elements in groundwater (Pavoni et al. 2018).

In the altered waters, compared to the natural ones (not affected by mining activities), elevated aluminum concentrations were also observed, reaching $0.4 \mathrm{mg} / \mathrm{L}$. Most probably, this element passes into the solution because of buffering acidic solutions resulting from oxidation of metal sulfides on aluminosilicates, mainly on clay minerals. Such minerals occur commonly in the Triassic carbonate rocks as karst fillings and/or as the marl or clay inserts.

Natural waters contain significantly higher amounts of boron than the transformed ones. In natural water, the concentration of this element falls within the range of 1.5 to $1.9 \mathrm{mg} / \mathrm{L}$ while in transformed waters, it is up to $0.388 \mathrm{mg} / \mathrm{L}$. Boron is an element present in elevated concentrations in natural waters associated with evaporates. Therefore, its higher concentration in waters dominated by chloride ion is justified. Waters infiltrating from overlying Triassic carbonate rocks have a significant share in transformed water and initially present low TDS values, without characteristics of water associated with evaporates, so presumably, the concentrations of boron in these waters were at low levels (i.e., of parts of $\mathrm{mg} / \mathrm{L}$ ).

\section{Conclusions}

At the initial stage of mining drainage, groundwater occurring in Permian molasse demonstrated the distinct natural, chemical zonation. With an increase in the depth, counted from the ceiling of these sediments, concentrations of $\mathrm{SO}_{4}$ and $\mathrm{Cl}$ ions increased, with a decreasing share of $\mathrm{HCO}_{3}$. Because of mining drainage, a significant decrease in TDS values of water occurred in a relatively short period of time. A long-term effect was the production of readily soluble hydroxysulphates of calcium, magnesium, and iron. It was a result of natural geochemical processes (i.e., oxidation of metal sulfides [mostly pyrite, marcasite, galena]). In waters from leaks that were active for over 40 years, a significant change in TDS value and the chemical type took place. It has changed from initial $\mathrm{Ca}-$ $\mathrm{Mg}-\mathrm{HCO}_{3}$ to $\mathrm{Ca}-\mathrm{Mg}-\mathrm{SO}_{4}$ and, in extreme cases, to $\mathrm{Mg}-\mathrm{SO}_{4}$.

Oxidation of sulfides generated large portions of acid solutions, thus creating favorable conditions for production of relatively mobile metal ions. However, in an environment of carbonate rocks, these solutions were buffered, and the $\mathrm{pH}$ value of water has not been changed significantly, but concentrations of some metals and other microelements have.

In waters flowing into mining works excavated in the Permian sediments, maximum concentrations of $\mathrm{Zn}$ increased to $69.8 \mathrm{mg} / \mathrm{L}, \mathrm{Fe}$ to about $40.6 \mathrm{mg} / \mathrm{L}$, and $\mathrm{Mn}$ to about $3.9 \mathrm{mg} /$ L. An increase in the concentration of toxic elements was also observed, especially Ni (up to $372 \mu \mathrm{g} / \mathrm{L}$ ), As (up to $155 \mu \mathrm{g} / \mathrm{L}$ ),
$\mathrm{Pb}$ (up to $190 \mu \mathrm{g} / \mathrm{L}$ ) of Cd (to $60 \mu \mathrm{g} / \mathrm{L}$ ), and Tl (to $81 \mu \mathrm{g} / \mathrm{L}$ ). The most severe concerns cause the presence of thallium, which is highly toxic and should be considered as an emerging pollutant associated with ore mining and processing. This requires future investigation.

Mine drainage and induced changes in the chemical composition of groundwater should always be considered when assessing environmental impacts of mining activities. Neutral mine drainage has less dramatic consequences than acid drainage, but still, it may cause an increase in concentrations of toxic elements in groundwater. Presently, contamination of groundwater within Permian sediments does not present a significant threat to the environment due to relatively low permeability (compared to Triassic limestones and dolomites), thus the negligible role of this aquifer in general groundwater flow.

Funding information This research was financially supported by the Polish Ministry of Science and Higher Education and AGH University (statutory research no. 11.11.140.797).

Open Access This article is distributed under the terms of the Creative Commons Attribution 4.0 International License (http:// creativecommons.org/licenses/by/4.0/), which permits unrestricted use, distribution, and reproduction in any medium, provided you give appropriate credit to the original author(s) and the source, provide a link to the Creative Commons license, and indicate if changes were made.

\section{References}

98/83EC 91998) Council Directive 98/83/EC of 3 November 1998 on the quality of water intended for human consumption. Official Journal L 330:0032-0054

Adamczyk AF (1990) The influence of $\mathrm{Zn}-\mathrm{Pb}$ ore mining in Olkusz area on groundwater and surface waters. Zeszyty Naukowe AGH, 1368, Sozologia i Sozotechnika, 32: 41-56 (in Polish)

Adamczyk AF, Motyka J, Wilk Z, Witczak S (1978) Salt water in Permian sediments on the north-eastern border of the upper Silesia Coal Basin. Ann Soc Geol Pol 48(3-4):537-558 (in Polish)

Aykol A, Budakoglu M, Kumral M, Gultekin AH, Turhan M, Esenli V, Yavuz F, Orgun Y (2003) Heavy metal pollution and acid drainage from the abandoned Balya $\mathrm{Pb}-\mathrm{Zn}$ sulfide mine, NW Anatolia, Turkey. Environ Geol 45:198-208

Bagchi D, Stohs SJ, Downs BW, Bagchi M, Preuss HG (2002) Cytotoxicity and oxidative mechanisms of different forms of chromium. Toxicology 180:5-22

Banks D, Younger PL, Arnesen RT, Iversen ER, Banks SB (1997) Minewater chemistry: the good, the bad and the ugly. Environ Geol 32: $157-174$

Bauerek A, Bebek M, Sracek O, Smieja-Krol B (2013) Chemical composition of surface runoff from flotation wastes of $\mathrm{Zn}-\mathrm{Pb}$ ore formation of the Mississippi Valley-type, Olkusz, Southern Poland. J Geochem Explor 132:54-62

Belzile N, Chen Y-W (2017) Thallium in the environment: a critical review focused on natural waters, soils, sediments and airborne particles. Appl Geochem 84:218-243

Borgmann U, Cheam V, Norwood WP, Lechner J (1998) Toxicity and bioaccumulation of thallium in Hyalella azteca, with comparison to 
other metals and prediction of environmental impact. Environ Pollut 99(1):105-114

Brix KV, Esbaugh AJ, Grosell M (2011) The toxicity and physiological effects of copper on the freshwater pulmonate snail, Lymnaea stagnalis. Comp Biochem Physiol C 154:261-267

Buła Z (2000) The lower Palaeozoic of Upper Silesia and west Małopolska. Prace Państwowego Instytutu Geologicznego 171, 89p (in Polish)

Cidu R, Biagini C, Fanfani L, La Ruffa G, Marras I (2001) Mine closure at Monteponi (Italy): effect of the cessation of dewatering on the quality of shallow groundwater. Appl Geochem 16(5):489-502

Cidu R, Bidau R, Fanfani L (2009) Impact of past mining activity on the quality of groundwater in SW Sardinia (Italy). J Geochem Explor 100:125-132

Cidu R, Biddau R, Nieddu G (2007) Rebound at $\mathrm{Pb}-\mathrm{Zn}$ mines hosted in carbonate aquifers: influence on the chemistry of ground water. Mine Water Environ 26:88-101

Cidu R, Biddau R, Spano T (2005) Temporal variations in water chemistry at abandoned mines hosted in a carbonate environment. Mine Water Environ 24:77-87

De Schamphelaere KAC, Forrez I, Dierckens K, Sorgeloos P, Janssen CR (2007) Chronic toxicity of dietary copper to Daphnia magna. Aquat Toxicol 81:409-418

Ebrahimpour M, Alipour H, Rakhshah S (2010) Influence of water hardness on acute toxicity of copper and zinc on fish. Toxicol Ind Health 26(6):361-365

Frau F, Ardau C, Fanfani L (2009) Environmental geochemistry and mineralogy of lead at the old mine area of Baccu Locci (southEast Sardinia, Italy). J Geochem Explor 100:105-115

Grande JA, Jimenez A, Borrego J, de la Torre ML, Gomez T (2010) Relationships between conductivity and $\mathrm{pH}$ in channels exposed to acid mine drainage processes: study of a large mass of data using classical statistics. Water Resour Manag 24:4579-4587

Grande JA, Santisteban M, de la Torre ML, Davila JM, Perez-Ostal E (2018) Map of impact by acid mine drainage in the river network of The Iberian Pyrite Belt (Sw Spain). Chemosphere 199(2018):269-277

Grande JA, Santisteban M, de la Torre ML, Valente T, Perez- Ostale E. (2013) Characterisation of AMD pollution in the reservoirs of the Iberian Pyrite Belt. Mine Water Environ 32:321-330

Gray NF (1997) Environmental impact and remediation of acid mine drainage: a management problem. Environ Geol 30:62-71. https:// doi.org/10.1007/s002540050133

Hermann R, Neumann-Mahlkau P (1985) The mobility of zinc, cadmium, copper, lead, iron and arsenic in ground water as a function of redox potential and $\mathrm{pH}$. Sci Total Environ 43(1-2):1-12

Hidalgo MC, Rey J, Benavente J (2010) Hydrogeochemistry of abandoned $\mathrm{Pb}$ sulphide mines: the mining district of La Carolina (southern Spain). Environ Earth Sci 61:37-46

Hogstrand C, Wood HM (1998) Toward a better understanding of the bioavailability, physiology, and toxicity of silver in fish: implications for water quality criteria. Environ Toxicol Chem 17(4):547-561

Johnson DB, Hallberg KB (2005) Acid mine drainage remediation options: a review. Sci Total Environ 338(1-2):3-14. https://doi.org/10. 1016/j.scitotenv.2004.09.002

Kazantzis G (2000) Thallium in the environment and health effects. Environ Geochem Health 22:275-280

Leblanc M, Morales JM, Borrego J, Elbaz-Poulichet F (2000) 4,500 yearold mining pollution in Southwestern Spain: long-term implications for modern mining pollution. Econ Geol 95:655-662

Lee JY, Choi JC, Lee KK (2005) Variations in heavy metal contamination of stream water and groundwater affected by an abandoned leadzinc mine in Korea. Environ Geochem Health 27:237-257

Lee CH, Lee HK, Lee JC (2001) Hydrogeochemistry of mine, surface and groundwaters from the Sanggok mine creek in the upper Chungju Lake, Republic of Korea. Environ Geol 40(4-5):482-494
Lukaszewski Z, Jakubowska M, Zembrzuski W (2018) The mobility of thallium from bottom soil of the Silesian-Cracowian zinc-lead ore deposit region (Poland). J Geochem Explor 184:11-16

Majzlan J, Števkob M, Chovanc M, Luptáková J, Milovská S, Milovský R, Jeleň S, Sýkorová M, Kilian Pollok K, Göttlicher J, Kupka D (2018) Mineralogy and geochemistry of the copper-dominated neutral mine drainage at the cu deposit Lubietová-Podlipa (Slovakia). Appl Geochem 92:59-70

Marr JCA, Hansen JA, Meyer JS, Cacela D, Podrabsky T, Lipton J, Bergman HL (1998) Toxicity of cobalt and copper to rainbow trout: application of a mechanistic model for predicting survival. Aquat Toxicol 43(4):225-238

Mayer W, Sass-Gustkiewicz M (1998) Geochemical characterization of sulphide minerals from the Olkusz lead-zinc ore cluster, Upper Silesia (Poland), based on laser ablation data. Mineral Pol 29:87-105

Motyka J (1988) Triassic carbonate sediments of Olkusz-Zawiercie orebearing district as an aquifer. Scientific Bulletins of Stanislaw Staszic Academy of Mining and Metallurgy No 1157, Geology 36 (in Polish)

Motyka J (1998) A conceptual model of hydraulic networks in carbonate rocks, illustrated by examples from Poland. Hydrogeol J 6:469-482

Motyka J, Czop M (2006) Geochemical evolution of the groundwater from Permian molasses in "Pomorzany" $\mathrm{Zn}-\mathrm{Pb}$ mine (Olkusz ore district, S Poland). Geochim Cosmochim Acta 70(18), Suppl. August-Sept):432

Motyka J, Postawa A (2013) Impact of Zn-Pb mining of the Olkusz ore district on the Permian aquifer (SW Poland). Environ Sci Pollut Res 20:7582-7589

Motyka J, Wilk Z (1976) Vertical differentiation in the water permeability of carbonate Triassic rocks in the light of a statistical analysis of the results of pumping tests (Silesia-Cracow monocline). Geol Q 20(2): 381-399 (in Polish)

Pavoni E, Covelli S, Adami G, Baracchini E, Cattelan R, Crosera M, Higueras P, Lenaz D, Petranich E (2018) Mobility and fate of thallium and other potentially harmful elements in drainage waters from a decommissioned $\mathrm{Zn}-\mathrm{Pb}$ mine (north-eastern Italian Alps). J Geochem Explor 188:1-10

Riyaz R, Pandalai SL, Schwartz M, Kazzi ZN (2013) A fatal case of thallium toxicity: challenges in management. J Med Toxicol 9(1): $75-78$

Sainz A, Grande JA, de la Torre ML (2003) Odiel River, acid mine drainage and current characterisation by means of univariate analysis. Environ Int 29:51-59

Sainz A, Grande JA, de la Torre ML (2004) Characterisation of heavy metal discharge into the Ria of Huelva. Environ Int 20:557-566

Sass-Gustkiewicz M (1997) Revised and completed paragenetic order of minerals in the Pomorzany lead-zinc deposit, Upper Silesian District, Poland. Mineral Pol 28(2):67-80

Sracek O, Filip J, Mihaljevič M, Kř́bek B, Majer V, Veselovský F (2011) Attenuation of dissolved metals in neutral mine drainage in the Zambian Copperbelt. Environ Monit Assess 172:287-299

Sracek O, Kř́bek B, Mihaljevič M, Majer V, Veselovský F, Vencelides Z, Nyambe I (2012) Mining-related contamination of surface water and sediments of the Kafue River drainage system in the Copperbelt district, Zambia: an example of a high neutralization capacity system. J Geochem Explor 112:174-188

WHO (2011) Guidelines for drinking-water quality $4^{\text {th }}$ edition. ISBN 978 9241548151 . Printed in Malta by Gutenberg

Wilk Z, Motyka J (1977) Hydraulic contacts between aquifers in Olkusz ore-mining region. Rocz Pol Towarz Geol 47(1):115-143 (in Polish)

Xiao T, Yang F, Li S, Zheng B, Ning Z (2012) Thallium pollution in China: a geoenvironmental perspective. Sci Total Environ 421422:51-58

Younger PL (1997) The longevity of minewater pollution: a basis for decision-making. Sci Total Environ 194(195):457-466 